\title{
GERMINATION AND VIGOR OF Bixa orellana L. SEEDS PRE-SOAKED IN A PLANT BIOSTIMULANT
}

\author{
Aderson Costa Araujo Neto ${ }^{1 *}$, Olívia Oliveira dos $\operatorname{Santos}^{1}$, Darlaine Maria Ferreira ${ }^{1}$, Renan Thiago \\ Carneiro Nunes ${ }^{1}$, Ana Paula Prado Barreto Públio ${ }^{1}$, Cláudio Lúcio Fernandes Amaral ${ }^{2}$ \\ ${ }^{1}$ State University of Southwestern Bahia , Vitória da Conquista, Bahia, Brazil - aderson_biologo@ hotmail.com; \\ olvagro@yahoo.com.br; laine_agro@ hotmail.com; renanthiago_tn@ hotmail.com; agrobarret@hotmail.com \\ ${ }^{2}$ State University of Southwestern Bahia, Department of Biological Sciences, Jequié, Bahia, Brazil- \\ claudio.lucio@uesb.edu.br \\ Received for publication: 14/11/2015 - Accepted for publication: 20/03/2018
}

\begin{abstract}
The aim of this study was to assess the germination and vigor of Bixa orellana seeds that were pre-soaked in different concentrations of Stimulate ${ }^{\circledR}$ plant biostimulant. For the standard germination test, Bixa orellana seeds from the Embrapa 37 Cultivar were pre-soaked (for periods of four and eight hours) in the following concentrations of Stimulate ${ }^{\circledR}$ aqueous solution: $3.0 ; 6.0 ; 9.0$; and $12.0 \mathrm{~mL} \mathrm{~L}^{-1}$. Seeds that were pre-soaked in distilled water were used as control. The following parameters were tested: germination; first germination count; abnormal seedlings; length; and seedling dry mass. The experimental design was completely randomized and a 2 × $5+1$ factorial design was used (with two pre-soaking periods, five Stimulate ${ }^{\circledR}$ concentrations, and one additional control without pre-soaking). Four replicates of 50 seeds were performed for each treatment. Water immersion treatments for four and eight hours were efficient for breaking dormancy in Bixa orellana seeds, since they promoted better germination in relation to the intact seeds that were not pre-soaked. The presoaking of Bixa orellana seeds for eight hours in a $12.0 \mathrm{~mL} \mathrm{~L}^{-1}$ Stimulate ${ }^{\circledR}$ concentration presented the best results in terms of germinative performance and seedling growth, with greater accumulation of dry mass. Therefore, this practice is recommended for the production of seedlings of this species.

Keywords: Annatto, Stimulate ${ }^{\circledR}$, growth, seedling production.
\end{abstract}

\section{Resumo}

Germinação e vigor de sementes de Bixa orellana L. submetidas à pré-embebição em bioestimulante. Objetivou-se com este trabalho avaliar a germinação e o vigor de sementes de B. orellana pré-embebidas em diferentes concentrações do bioestimulante vegetal Stimulate ${ }^{\circledR}$. Para o teste padrão de germinação, sementes de $B$. orellana da cultivar Embrapa 37 foram pré-embebidas nas concentrações de 3,0; 6,0;9,0 e 12,0 mL de Stimulate ${ }^{\circledR} \mathrm{L}^{-1}$ de solução aquosa, durante os períodos de quatro e oito horas, tendo como controle a préembebição de sementes em água destilada. Os parâmetros avaliados foram: germinação; primeira contagem de germinação; plântulas anormais; comprimento; e massa seca de plântulas. O delineamento experimental foi inteiramente casualizado, em esquema fatorial $2 \times 5+1$ (dois tempos de pré-embebição, cinco concentrações de Stimulate ${ }^{\circledR}$, e uma testemunha adicional sem pré-embebição), com quatro repetições de 50 sementes por tratamento. Os tratamentos de imersão em água por quatro e oito horas foram eficientes na quebra de dormência das sementes de $B$. orellana, promovendo germinação superior em relação às intactas sem pré-embebição. A pré-embebição de sementes de $B$. orellana por um período de oito horas na concentração de $12,0 \mathrm{~mL}$ de Stimulate ${ }^{\circledR} \mathrm{L}^{-1}$ de solução proporcionou melhor desempenho germinativo e formação de plântulas com maior acúmulo de massa seca. Assim, recomenda-se essa prática para a produção de mudas dessa espécie.

Palavras-chave: Urucum, Stimulate ${ }^{\circledR}$, crescimento, produção de mudas.

\section{INTRODUCTION}

Bixa orellana L. (Family Bixaceae) is a tropical American woody plant, native to the Amazon and Atlantic forests. In Brazil, it is known as annatto, urucu, and safflower (Carthamus), among other names. It is commonly used as an ornamental plant - because of its beauty and colorful flowers - and as a medicinal plant. It is also often used in the recovery of degraded areas, due to its rapid growth (LORENZI; MATOS, 2008). Its seeds are valuable for the production of pigments that are used as a natural dye in food, pharmaceutical, cosmetics, and poultry industries (HARDER et al., 2008).

However, the sexual propagation of this species is made difficult by the low percentage of germination of its seeds, which occurs due to the dormancy imposed by integument impermeability (AMARAL et al., 1995; CORLETT et al., 2007; LOPES et al., 2008). Treatments that cause the acceleration and improvement of germination are essential, since it is important that seeds germinate rapidly and uniformly in seedling production,

FLORESTA, Curitiba, PR, v. 48, n. 3, p. 293-302, jul/set. 2018

Neto, A.C.A. et.al.

ISSN eletrônico 1982-4688

DOI: $10.5380 /$ rf.v.48 i3.43934 
which results in shorter time in nursery, uniform seedlings, and lower costs, as well as simpler planting schedules (KISSMANN et al., 2011).

Many techniques for pre-sowing treatment have been proposed, aiming to: a) reduce the time required between sowing and the emergence of seedlings; and b) increase the resistance of seeds to different types of environmental stress (SCALON et al., 2014). Plant biostimulants may be used to accelerate and improve seed germination, and also to promote the growth of seedlings of several species (PRADO NETO et al., 2007; LIMA et al., 2009; SCALON et al., 2009; KISSMANN et al., 2011; PIEREZAN et al., 2012).

The mixture of two or more plant regulators, or of plant regulators with other substances (amino acids, nutrients, vitamins), is called biostimulant (or plant stimulant). This chemical product can increase plant growth and development, thus stimulating the cell division, differentiation, and elongation. It may also enhance the absorption and use of water and nutrients by plants (VIEIRA; CASTRO, 2001).

Stimulate ${ }^{\circledR}$ is able to trigger root development, thus increasing the absorption of water and nutrients by roots, and possibly promoting the hormonal balance of the plant (SANTOS; VIEIRA, 2005). According to Dantas et al. (2012), the use of growth regulators during the early stages of plant development promotes root growth, enables rapid recovery after water stress, increases resistance to insects, pests, diseases and nematodes, and promotes the quick and uniform establishment of plants, which in turn improves nutrient absorption and yield.

Since seed dormancy hinders the production of Bixa orellana seedlings and regulators present in Stimulate ${ }^{\circledR}$ may attenuate problems related to the physiological processes of germination and seedling growth, the objective of this study was to assess the germination and seed vigor of Bixa orellana pre-soaked in different concentrations of Stimulate ${ }^{\circledR}$.

\section{MATERIAL AND METHODS}

This study was conducted in the Seed Technology Laboratory of the State University of Southwestern Bahia, Vitória da Conquista campus. Mature Bixa orellana seeds from the Embrapa 37 Cultivar were used. The seeds were freshly harvested from commercial plantations at Fazenda Sempre Viva, located at the BR-367 highway, in the city of Eunápolis, state of Bahia, Brazil (16 $40^{\prime} \mathrm{S}$ and $\left.39^{\circ} 34^{\prime} \mathrm{W}\right)$. This region is characterized as tropical and humid, with no specific dry season (based on the Köppen climate classification). The land was classified as sandy clay loam soil (EMBRAPA, 2006).

Initially, before the soaking treatments, the intact seeds were assessed for their germinative capacity through a germination test. They also went through the first germination count. The seeds were then pre-soaked for four and eight hours, in $0.0,3.0,6.0,9.0$, and $12.0 \mathrm{~mL} \mathrm{~L}^{-1}$ liquid solutions of Stimulate ${ }^{\circledR}$ commercial biostimulant. The biostimulant was composed of $0.009 \%\left(90 \mathrm{mg} \mathrm{L}^{-1}\right)$ kinetin (cytokinin), $0.005 \%\left(50 \mathrm{mg} \mathrm{L}^{-1}\right)$ gibberellic acid (gibberellin), $\quad 0.005 \% \quad\left(50 \quad \mathrm{mg}^{-1}\right)$ indolebutyric acid (auxin), and $99.981 \%$ inert ingredients (STOLLER DO BRASIL, 1998).

After pre-soaking, seed germination and vigor were assessed according to the following variables:

a) Standard germination test: conducted on paper substrate (wound into rolls), with four replicates of 50 seeds per treatment, over three Germitest ${ }^{\circledR}$ sheets - two used as a base, and another one used for covering. The sheets were moistened with distilled water, in the amount of 2.5 times their dry mass (BRASIL, 2009). The rolls were placed in plastic polyethylene bags, in order to prevent moisture loss. They were kept in a germinator at a constant temperature of $25^{\circ} \mathrm{C}$. Counting took place 21 days after sowing, and the number of normal seedlings of each replicate was computed (PICOLOTTO et al., 2013);

b) First germination count: cumulative percentage of normal seedlings on the $14^{\text {th }}$ day after sowing (PICOLOTTO et al., 2013). Seedlings with perfect structure were considered normal (BRASIL, 2009). It was held concurrently with the germination test;

c) Abnormal seedlings: percentage of seedlings with some type of abnormality in one of their essential structures, which made their development unfeasible (BRASIL, 2009). This percentage was computed at the end of the standard germination test;

d) Seedling length: at the end of the germination test, the normal seedlings of each replicate were used to measure the length from the root end to the insertion of cotyledons. A ruler (in centimeters) was utilized for this procedure. The results were expressed in centimeters per seedling;

e) Dry seedling mass: determined through the seedlings from the seedling length evaluation. The seedlings were placed in $\mathrm{Kraft}^{\circledR}$ paper bags and packaged in a forced air circulation oven, set at $65^{\circ} \mathrm{C}$. They remained there until they reached constant weight. They were then weighed on an analytical scale $(0.0001 \mathrm{~g}$ accuracy). The results were expressed in grams per seedling.

The experimental design was randomized and a $2 \times 5+1$ factorial design was used, with two pre-soaking periods (4 and 8 hours), five Stimulate ${ }^{\circledR}$ concentrations $\left(0.0 ; 3.0 ; 6.0 ; 9.0\right.$; and $12.0 \mathrm{~mL} \mathrm{~L}^{-1}$ ), and one additional 
control (without pre-soaking). Four replicates of 50 seeds were performed for each treatment. Untransformed data were submitted to analysis of variance (ANOVA). The F test was used to determine any differences between mean squares. Differences between means were determined by Tukey's test (at $5 \%$ significance level). For quantitative effects, a polynomial regression analysis was performed. The significant models $(F \leq 0.05)$ were selected $\left(R^{2} \geq\right.$ $60 \%$ ), and ASSISTAT (statistical program), beta version 7.7, was used.

\section{RESULTS}

There was a significant interaction between pre-soaking time and Stimulate $^{\circledR}$ plant biostimulant concentrations $(\mathrm{p}<0.01)$ for all variables (Table 1$)$.

Table 1. Summary of ANOVA results for germination (G), first count (FC), abnormal seedlings (AS), length (L), and seedling dry mass (SDM) of Bixa orellana L. from pre-soaked seeds in different concentrations of Stimulate ${ }^{\circledR}$.

Tabela 1. Resumo da análise de variância dos dados referentes a germinação (G), primeira contagem (PC), plântulas anormais (PA), comprimento (CP) e massa seca de plântulas (MSP) de Bixa orellana L. originadas por sementes pré-embebidas em diferentes concentrações de Stimulate ${ }^{\circledR}$.

\begin{tabular}{ccccccc}
\hline \multirow{2}{*}{ S.V. } & DF & \multicolumn{5}{c}{ Mean squares } \\
\cline { 3 - 7 } & 1 & G & FC & AS & L & SDM \\
\hline Time & $562.5^{* *}$ & $765.62^{* *}$ & $4.92^{* *}$ & $1.30^{*}$ & $0.02^{* *}$ \\
Conc & 4 & $187.1^{*}$ & $232.4^{* *}$ & $0.41^{* *}$ & $5.96^{* *}$ & $0.004^{* *}$ \\
Time * conc & 4 & $451.0^{* *}$ & $470.0^{* *}$ & $0.66^{* *}$ & $1.36^{* *}$ & $0.011^{* *}$ \\
Error & 30 & $52.16^{* *}$ & 16.02 & 0.03 & 0.26 & 0.001 \\
Cv (\%) & & 11.83 & 6.82 & 15.2 & 4.44 & 24.96 \\
Overall mean & & 61.05 & 58.72 & 3.6 & 11.61 & 0.13
\end{tabular}

SV: sources of variation; DF: Degrees of freedom; TIME: pre-soaking time; CONC: Stimulate ${ }^{\circledR}$ concentration; CV: Coefficient of variation. Significant values obtained through the F-test at $1 \%(* *)$ and $5 \%(*)$; NS: not significant.

By calculating the percentage of seed germination after pre-soaking in water (control), it was possible to verify that there was a considerable increase (around 40\%) in the germinative performance of B. orellana immersed in Stimulate ${ }^{\circledR}$ solution for 4 and 8 hours, when compared to seeds with no prior soaking (Table 2). These results suggest that the treatments were effective in breaking seed dormancy, which was caused by the impermeability of the tegument to water, as reported by Mendes et al. (2006). In this case, because the seeds were immersed in water for long periods of time, the integument may have gone through a degradation process, which favored the entry of water into the seed and consequently led to germination.

Table 2. Germination and first germination count of Bixa orellana L. seeds pre-soaked in water for different periods of immersion.

Tabela 2. Germinação e primeira contagem da germinação de sementes de Bixa orellana L. pré-embebidas em água por diferentes períodos de imersão.

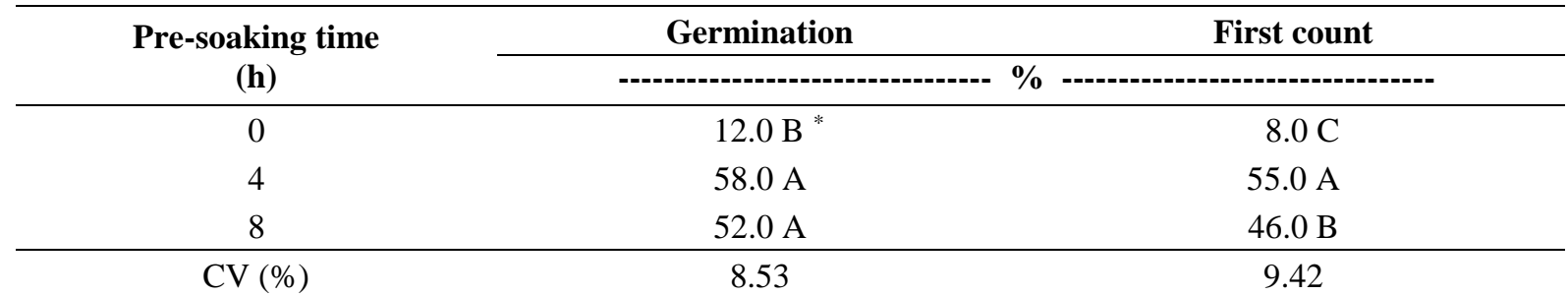

${ }^{*}$ Mean values followed by the same letter in the columns are not significantly different from one another, based on Tukey's test results (5\% significance level).

Regarding the germination percentage of B. orellana seeds pre-soaked in plant biostimulant (Figure 1), values for the 4-hour pre-soaking period were found to be slightly variable in relation to the control $\left(0 \mathrm{~mL} \mathrm{~L}^{-1}\right.$ Stimulate $^{\circledR}$ ). The average germination percentage, in this case, was $60 \%$ (up to $6.0 \mathrm{~mL} \mathrm{~L}^{-1}$ of Stimulate ${ }^{\circledR}$ solution).

FLORESTA, Curitiba, PR, v. 48, n. 3, p. 293-302, jul/set. 2018

Neto, A.C.A et.al.

ISSN eletrônico 1982-4688

DOI: $10.5380 /$ rf.v.48 i3.43934 
Thereafter, from $6.0 \mathrm{~mL}$ to $12.0 \mathrm{~mL} \mathrm{~L}^{-1}$ of Stimulate ${ }^{\circledR}$, there was a decrease in germination percentage values (the lowest percentage found was $49 \%$ ).

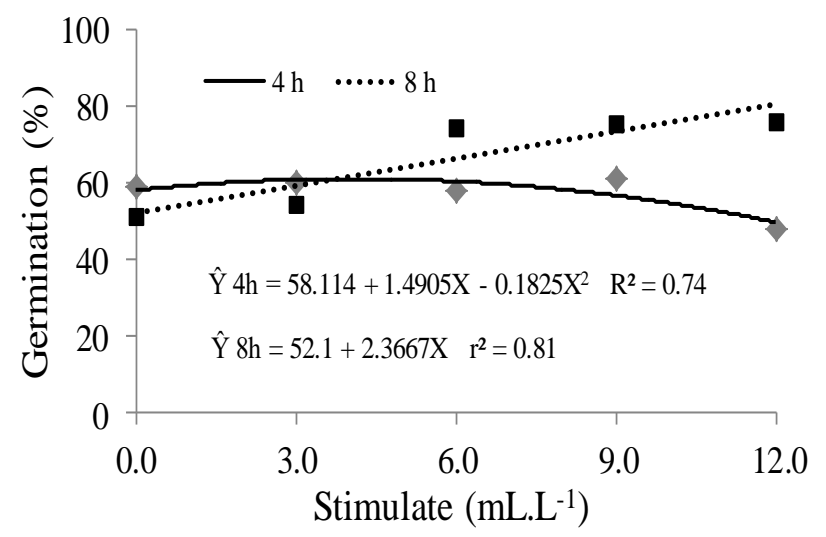

Figure 1. Germination (\%) of Bixa orellana L. seeds pre-soaked in different concentrations of Stimulate ${ }^{\circledR}$ for two periods of time (4 and 8 hours).

Figura 1. Germinação (\%) de sementes de Bixa orellana L. pré-embebidas em diferentes concentrações de Stimulate ${ }^{\circledR}$ por dois períodos (4 e 8 horas).

For seeds pre-soaked for 8 hours, there was an increase in the germination percentage, which correlated with the increase in the concentration of the biostimulant (Figure 1). The highest percentage (80.5\%) was observed for the $12.0 \mathrm{~mL} \mathrm{~L}^{-1}$ concentration of Stimulate ${ }^{\circledR}$, which represents an increase of $28 \%$ in relation to the control $\left(0 \mathrm{~mL} \mathrm{~L}^{-1}\right.$ Stimulate $\left.^{\circledR}\right)$, and of $68 \%$ in relation to the seeds that were not pre-soaked (Table 2).

For the first germination count, there was little variation between the seeds pre-soaked for 4 hours and the control $\left(0 \mathrm{~mL} \mathrm{~L}{ }^{-1}\right.$ Stimulate $\left.^{\circledR}\right)$. The average percentage was $58 \%$ (up to $6.0 \mathrm{~mL} \mathrm{~L}^{-1}$ Stimulate $^{\circledR}$ solution). However, for higher concentrations (up to $12.0 \mathrm{~mL} \mathrm{~L}^{-1}$ of Stimulate ${ }^{\circledR}$ ), there was a decrease in the percentage values of the first germination count. The lowest result, in this case, was below 47\% (Figure 2).

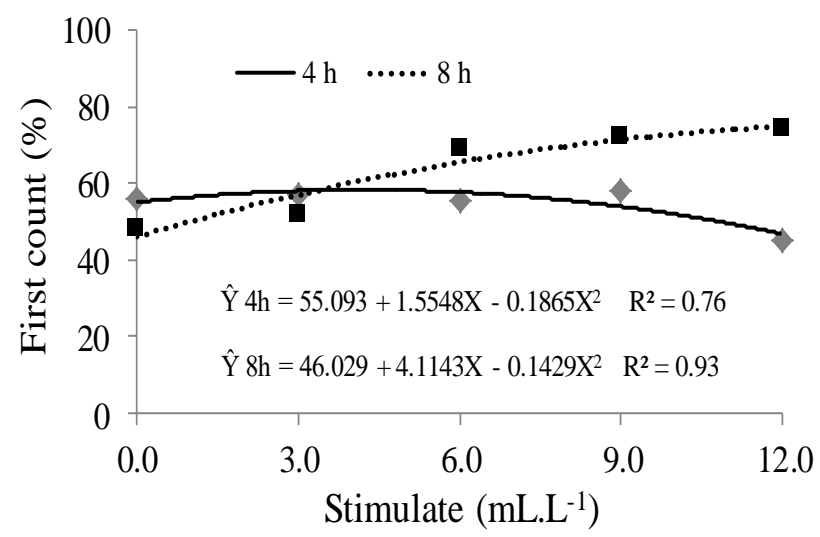

Figure 2. First germination count $(\%)$ of Bixa orellana L. seeds pre-soaked in different concentrations of Stimulate $^{\circledR}$ for two periods of time (4 and 8 hours).

Figura 2. Primeira contagem de germinação (\%) de sementes de Bixa orellana L. pré-embebidas em diferentes concentrações de Stimulate ${ }^{\circledR}$ por dois períodos (4 e 8 horas).

For seeds pre-soaked for 8 hours, an increase in the germination percentage was observed, which correlated with the increase in the concentration of the biostimulant (Figure 2). This result was similar to that observed at the end of the test (Figure 1). Thus, the highest percentage (75\%) was recorded for the $12.0 \mathrm{~mL} \mathrm{~L}^{-1}$ Stimulate ${ }^{\circledR}$ concentration, which represents an increase of $29 \%$ in relation to the control $\left(0 \mathrm{~mL} \mathrm{~L}^{-1} \mathrm{Stimulate}^{\circledR}\right)$, and of $67 \%$ in relation to the seeds that were not pre-soaked (Table 2). This result indicates a positive effect of these substances on the germination performance of B. orellana seeds. 
Regarding the percentage of abnormal seedlings, a trend towards an increase was observed for seedlings in the four-hour pre-soaking period. The total percentage of abnormal seedlings for the estimated maximum value of $5.6 \mathrm{~mL} \mathrm{~L}^{-1}$ of Stimulate ${ }^{\circledR}$ solution was $4.4 \%$. However, for higher concentration values (up to $12.0 \mathrm{~mL} \mathrm{~L}^{-1}$ of Stimulate $\left.{ }^{\circledR}\right)$, there was a progressive decrease in this percentage. The lowest result, in this case, was $1 \%$ (Figure 3 ).

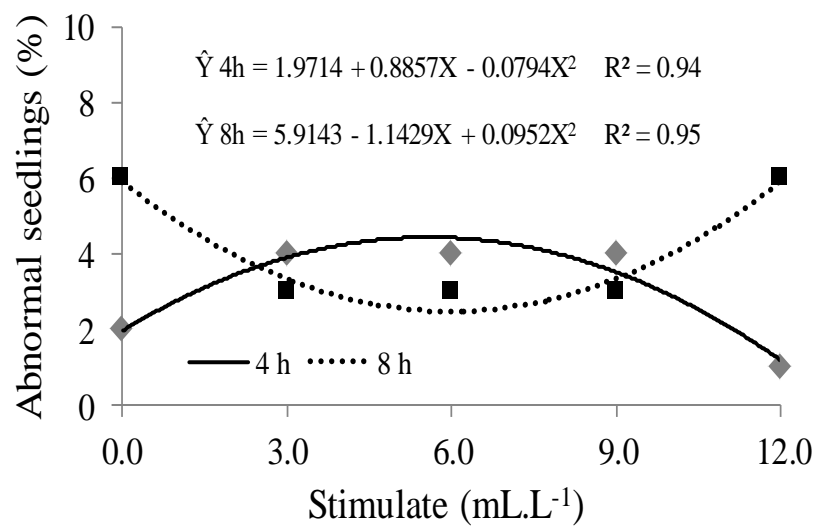

Figure 3. Abnormal (\%) Bixa orellana L. seedlings originated from seeds that were pre-soaked in different concentrations of Stimulate ${ }^{\circledR}$ (4 and 8 hours).

Figura 3. Plântulas anormais (\%) de Bixa orellana L. originadas por sementes pré-embebidas em diferentes concentrações de Stimulate ${ }^{\circledR}$ por dois períodos (4 e 8 horas).

The opposite was found for seeds pre-soaked for 8 hours. In this case, there was a trend towards decrease in the percentage of abnormal seedlings. The lowest percentage (for $6.0 \mathrm{~mL} \mathrm{~L}^{-1}$ of Stimulate ${ }^{\circledR}$ ) was $2.5 \%$. There was then an increase in the formation of these seedlings. For $12.0 \mathrm{~mL} \mathrm{~L}^{-1}$ of Stimulate ${ }^{\circledR}$, the percentage of abnormal seedlings $(6 \%)$ was similar to that obtained for the control $\left(0 \mathrm{~mL} \mathrm{~L}^{-1}\right.$ of Stimulate ${ }^{\circledR}$ solution $)$. Therefore, it was observed that intermediate concentrations of the biostimulant promoted a lower percentage of abnormal $B$. orellana seedlings for a longer pre-soaking period (8 hours) (Figure 3 ).

As for seedling length, it was found that during the two pre-soaking periods (four and eight hours), there was a significant decrease in the size of seedlings, which negatively correlated with the increase of Stimulate ${ }^{\circledR}$ concentrations. The largest seedlings $(12.8$ and $12.4 \mathrm{~cm})$ were formed from control seeds $\left(0 \mathrm{~mL} \mathrm{~L}^{-1}\right.$ of Stimulate $\left.{ }^{\circledR}\right)$, and the smallest ones $(11.0$ and $10.1 \mathrm{~cm})$ originated from seeds immersed in $12.0 \mathrm{~mL} \mathrm{~L}^{-1}$ of Stimulate ${ }^{\circledR}$. This result suggests that the pre-soaking periods of the B. orellana seeds, at the highest concentrations of the biostimulant, present an inhibitory effect on the growth of seedlings (Figure 4).

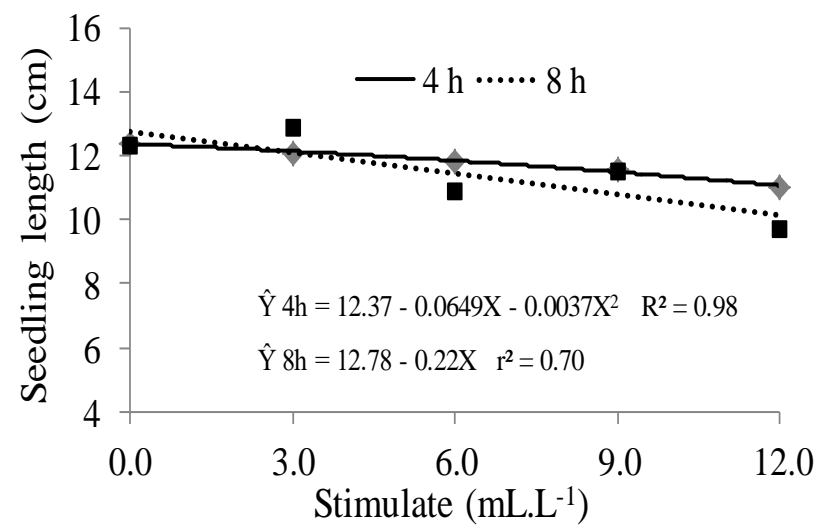

Figure 4. Length $(\mathrm{cm})$ of Bixa orellana L. seedlings originated from seeds that were pre-soaked in different concentrations of Stimulate $^{\circledR}$ (4 and 8 hours).

Figura 4. Comprimento de plântulas $(\mathrm{cm})$ de Bixa orellana L. originadas por sementes pré-embebidas em diferentes concentrações de Stimulate ${ }^{\circledR}$ por dois períodos (4 e 8 horas).

FLORESTA, Curitiba, PR, v. 48, n. 3, p. 293-302, jul/set. 2018

Neto, A.C.A. et.al.

ISSN eletrônico 1982-4688

DOI: $10.5380 /$ rf.v.48 i3.43934 
For seedling dry mass, there was a decrease on seedlings in the pre-soaking period of four hours (up to the estimated $7.0 \mathrm{~mL} \mathrm{~L}^{-1}$ concentration of Stimulate ${ }^{\circledR}$ solution). Thus, the lowest value for this variable $(0.09 \mathrm{~g})$ was obtained with $7.0 \mathrm{~mL} \mathrm{~L}^{-1}$ of Stimulate ${ }^{\circledR}$. Then, a gradual increase was observed (up to $0.13 \mathrm{~g}$ ) for concentrations up to $12.0 \mathrm{~mL} \mathrm{~L}^{-1}$ of the biostimulant. However, the highest dry mass value $(0.15 \mathrm{~g})$ was obtained for the control $\left(0 \mathrm{~mL} \mathrm{~L}^{-1}\right.$ of Stimulate $\left.{ }^{\circledR}\right)$. For the pre-soaking period of eight hours, there was an increase in the dry mass of seedlings, which correlated with the increase in the concentration of the biostimulant. The highest value $(0.23 \mathrm{~g})$ was attained for the $12.0 \mathrm{~mL} \mathrm{~L}^{-1}$ Stimulate $^{\circledR}$ concentration, and the lowest one was obtained for the control $\left(0 \mathrm{~mL} \mathrm{~L}^{-1}\right.$ of Stimulate $\left.{ }^{\circledR}\right)$. These results represented an increase of $61 \%$ (Figure 5 ).

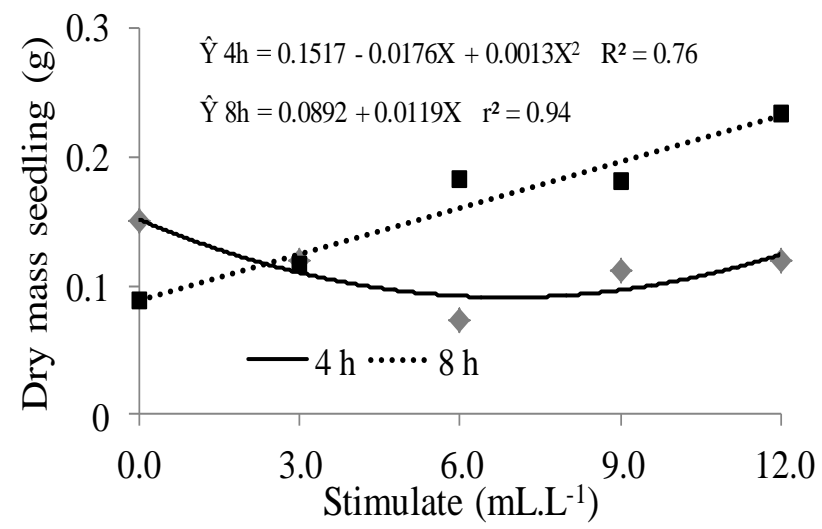

Figure 5. Dry mass (g) of Bixa orellana L. seedlings from seeds that were pre-soaked in different Stimulate ${ }^{\circledR}$ concentrations (4 and 8 hours).

Figura 5. Massa seca de plântulas (g) de Bixa orellana L. originadas por sementes pré-embebidas em diferentes concentrações de Stimulate ${ }^{\circledR}$ por dois períodos (4 e 8 horas).

\section{DISCUSSION}

The reduced germination capacity observed in seeds that were not pre-soaked (Table 2) was similar to that observed by Lopes et al. (2008) in mature and intact B. orellana seeds from the Casca Verde Cultivar. According to Amaral et al. (2000), in the last maturation stage of B. orellana seeds, there is an increase in impermeability of the integument to water, which culminates in a dormancy imposed by the tegument. This dormancy is responsible for the low germination of the species, since the germinative process is not initiated in the absence of water.

These results contradict findings presented by Morais and São José (1990), who recommend the presoaking of seeds in room temperature for a period of 6 to 12 hours, in order to guarantee greater success in B. orellana seedling production. These authors have also claimed that practicality and low cost are among the advantages of this method, when compared to different methods that are recommended in other studies, such as mechanical scarification with sandpaper, and chemical scarification with immersion in sulfuric acid (AMARAL et al., 1995; CORLETT et al., 2007; PICOLOTTO et al., 2013).

The increase in the germination percentage of $B$. orellana seeds, observed in the pre-soaking treatments of seeds in biostimulant solution for eight hours - with highest results for the $12.0 \mathrm{~mL} \mathrm{~L}^{-1}$ Stimulate $^{\circledR}$ concentration - was also found by Canesin et al. (2012). The authors concluded that treatments with $14 \mathrm{~mL}$ of Stimulate ${ }^{\circledR}$ per $0.5 \mathrm{~kg}$ of seeds, and $15 \mathrm{~mL}$ of Stimulate ${ }^{\circledR}$ per $0.5 \mathrm{~kg}$ of seeds increase the percentage and the emergence speed of fava d'anta (Dimorphandra mollis) seedlings. According to Santos et al. (2013b), this occurs because gibberellin stimulates the synthesis of enzymes that digest the reserves stored in the endosperm, forming simple sugars, amino acids, and nucleic acids. These compounds are absorbed and transported to the growing regions of the embryo, thus stimulating cell elongation, causing the root to rupture the seed integument and accelerating germination with greater uniformity. In addition to gibberellins, cytokinins and auxins, there are also part of various physiological development processes, including seed germination and bud dormancy break (TAIZ, ZEIGER, 2008).

However, the same trend towards an increase in germination - obtained when seeds were pre-soaked in Stimulate ${ }^{\circledR}$ - was not observed by Pierezan et al. (2012), who reported negative effects of growth regulators present in the plant biostimulant. According to these authors, the use of $35 \mathrm{~mL}$ of Stimulate ${ }^{\circledR}$ per $0.5 \mathrm{~kg}$ of seeds inhibited the germination process and the quality of West Indian locust seedlings (Hymenaea courbaril L.), 40 days after sowing. Lima et al. (2009) found that pre-soaking hard jackfruit seeds (Artocarpus heterophyllus Lam.) for 2 hours in 
Stimulate ${ }^{\circledR}$ solution $\left(5 \mathrm{~mL} \mathrm{~L}^{-1}\right.$ and $\left.10 \mathrm{~mL} \mathrm{~L}^{-1}\right)$ did not affect germination. Santos and Vieira (2005) verified that cotton (Gossypium hirsutum L.) seeds did not respond to the use of Stimulate ${ }^{\circledR}$ (in concentrations of up to $21 \mathrm{~mL} \mathrm{~L}^{-1}$ ).

Abnormal seedling formation for $B$. orellana was not influenced by the pre-soaking of seeds in the biostimulant solution for eight hours. This was the case independently of the concentration used, since the percentages recorded in the treatments were lower than those recorded for the control (Figure 3). Conversely, there was a significant increase in the germination percentage of seeds that were pre-soaked in a $12.0 \mathrm{~mL} \mathrm{~L}^{-1}$ Stimulate $^{\circledast}$ solution for eight hours (as opposed to the control), when the number of normal seedlings was taken into account. Therefore, considering the difficulty of germinating $B$. orellana, it is possible to infer that the hormonal treatment of the seeds with plant biostimulant improves their germinative performance and consequently increases the formation of normal seedlings. The treatment was thus effective and may be used to produce seedlings of this species.

However, unlike the results obtained in this study, Santos et al. (2013a) found that the prolonged presoaking (7 to 10 hours) of seeds in different concentrations of Stimulate ${ }^{\circledR}\left(1.0 ; 2.5 ; 4.0 ; 5.5\right.$; and $\left.7.0 \mathrm{~mL} \mathrm{~L}^{-1}\right)$ may have caused a phytotoxic effect, resulting in an increase in the percentage of abnormal sunflower seedlings (Helianthus annuиs L.).

Despite the positive impact on seed performance, the treatment with Stimulate ${ }^{\circledR}$ resulted in a decrease in the length of $B$. orellana seedlings, as a consequence of increased concentrations (Figure 4). This finding suggests that the higher concentrations tested (9.0 to $12.0 \mathrm{~mL} \mathrm{~L}^{-1}$ of Stimulate $\left.{ }^{\circledR}\right)$ may have been excessive, or that the presoaking periods may have been prolonged to a point in which an inhibitory effect on cell elongation and on the growth of seedlings took place. This effect was also observed on West Indian locust seedlings (H. courbaril) originated from seeds treated with higher concentrations of Stimulate ${ }^{\circledR}: 25$ and $35 \mathrm{~mL}$ per $0.5 \mathrm{~kg}$ of seeds (PIEREZAN et al., 2012). These results contradict those obtained by Vieira and Castro (2001), who verified that the effectiveness of the biostimulant depends on its composition, concentration, and proportion of substances. The biostimulant may both enhance plant growth, which stimulates cell division and increase the absorption of water and nutrients by plants.

Prado Neto et al. (2007) obtained positive results when they pre-soaked genipap (Genipa americana L.) seeds for 12 hours in a $10 \mathrm{~mL} \mathrm{~L}^{-1}$ Stimulate ${ }^{\circledast}$ solution. Their results contradict those observed in the present study. Prado Neto et al. (2007) observed that seedlings which were treated with plant biostimulant outgrew those that were not by $46.3 \%$. Kissman et al. (2011), however, observed that the treatment of carobinha seeds (Jacaranda decurrens subsp. Symmetrifoliolata Farias \& Proença) with $10 \mathrm{~mL}$ of Stimulate ${ }^{\circledR}$ per $0.5 \mathrm{~kg}$ of seeds and 100 and $200 \mathrm{mg} \mathrm{L}^{-1}$ of $\mathrm{GA}_{3}$ did not have any effect upon their growth, even though the treatment had positive results for seedling emergence and emergence speed.

The increase of dry mass in B. orellana seedlings - which was caused by the pre-soaking of seeds in a $12.0 \mathrm{~mL} \mathrm{~L}^{-1}$ Simulate ${ }^{\circledast}$ solution for a period of eight hours - was also observed in a study conducted by Scalon $e t$ al. (2009). The researchers found that the treatment of gabiroba (Campomanesia adamantium) seeds with Stimulate ${ }^{\circledR}$ $\left(0.2 \mathrm{~mL} \mathrm{~L}^{-1}\right)$ caused a significant increase in their dry mass, 145 days after sowing, as opposed to the control. Different results were obtained by Canesin et al. (2012), who concluded that the treatment of fava d'anta $(D$. mollis) seeds with tested concentrations of Stimulate ${ }^{\circledR}(15.0,20.0$ and $25.0 \mathrm{~mL}$ per $0.5 \mathrm{~kg}$ of seeds) did not have any effect on their length or dry mass.

In general, the pre-soaking of B. orellana seeds for a period of eight hours in the largest concentrations of Stimulate ${ }^{\circledast}\left(9.0\right.$ and $\left.12.0 \mathrm{~mL} \mathrm{~L}^{-1}\right)$ favored germination and the formation of seedlings with larger dry mass, despite the fact that it also caused a sensible reduction in seedling length. Finally, little is known about the actual effect of biostimulants on the physiological quality of seeds and on the growth of forest seedling species. In addition to it, the knowledge regarding the consequences of exposing seeds to these substances for different periods of time is still superficial, which suggests the need for further research.

\section{CONCLUSIONS}

- Water immersion treatments for four and eight hours are efficient in breaking B. orellana seed dormancy, which promotes better germination when compared to seeds that are intact and are not pre-soaked;

- The pre-soaking of $B$. orellana seeds in a $12.0 \mathrm{~mL} \mathrm{~L}^{-1}$ Stimulate ${ }^{\circledR}$ solution for eight hours leads to better germinative performance and to the formation of seedlings with greater dry mass.

\section{REFERENCES}

AMARAL, L. I. V.; PEREIRA, M. F. A.; CORTELAZZO, A. L. Germinação de sementes em desenvolvimento de Bixa orellana. Revista Brasileira de Fisiologia Vegetal, Campinas, v. 12, n. 3, p. 273 - 285, 2000.

FLORESTA, Curitiba, PR, v. 48, n. 3, p. 293-302, jul/set. 2018

Neto, A.C.A. et.al.

ISSN eletrônico 1982-4688

DOI: $10.5380 /$ rf.v.48 i3.43934 
AMARAL, L. I. V.; PEREIRA, M. F. A.; CORTELAZZO, A. L. Quebra da dormência em sementes de Bixa orellana. Revista Brasileira de Fisiologia Vegetal, Campinas, v. 7, n. 2, p. 151 - 157, 1995.

BRASIL. Ministério da Agricultura, Pecuária e Abastecimento. Regras para análise de sementes. Brasília: MAPA, 2009. 399 p.

CANESIN, A.; MARTINS, J. M. D. T.; SCALON, S. P. Q.; MASSETO, T. E. Bioestimulante no vigor de sementes e plântulas de faveiro (Dimorphandra mollis Benth.). Cerne, Lavras, v. 18, n. 2, p. 309 - $315,2012$.

CORLETT, F. M. F.; BARROS, A. C. S. A.; VILlELA, F. A. Qualidade fisiológica de sementes de urucum armazenadas em diferentes ambientes e embalagens. Revista Brasileira de Sementes, Londrina, v. 29, n. 2, p.148 - 158, 2007.

DANTAS, A. C. V. L.; QUEIROZ, J. M. O.; VIEIRA, E. L.; ALMEIDA, V. O. Effect of gibberellic acid and the bioestimulant Stimulate ${ }^{\circledR}$ on the initial growth of thamarind. Revista Brasileira de Fruticultura, Jaboticabal, v. 34, n. 1, p. $008-014,2012$.

EMPRESA BRASILEIRA DE PESQUISA AGROPECUÁRIA - EMBRAPA. Sistema brasileiro de classificação de solos. Rio de Janeiro: Embrapa Solos, 2006. 412 p.

HARDER, M. N. C.; BRAZACA, S. G. C.; SAVINO, V. J. M.; COELHO, A. A. D. Efeito de Bixa orellana na alteração de características de ovos de galinhas. Ciência e Agrotecnologia, Lavras, v. 32, n. 4, p. 1232 - 1237, 2008.

KISSMANN, C.; SCALON, S. P. Q.; SCALON FILHO, H.; VIEIRA, M. C. Biorregulador e pré-condicionamento osmótico na germinação de sementes e no crescimento inicial da muda de carobinha (Jacaranda decurrens subsp. symmetrifoliolata Farias e Proença) - Bignoniaceae. Revista Brasileira de Plantas Medicinais, Botucatu, v. 13, n. 1, p. $58-67,2011$.

LIMA, J. F.; FONSECA, V. J. A.; MORAES, J. C. C.; ALMEIDA, J.; VIEIRA, E. L.; PEIXOTO, C. P. Germinação de sementes pré-embebidas e crescimento de plantas de Artocarpus heterophyllus Lam. Scientia Agraria, Curitiba, v. 10, n. 6, p. 437 - 441, 2009.

LOPES, J. C.; LIMA, R. V.; MACEDO, C. M. P. Germinação e vigor de sementes de urucu. Horticultura Brasileira, Vitória da Conquista, v. 26, n. 1, p. 19 - 252008.

LORENZI, H.; MATOS, F. J. A. Plantas medicinais no Brasil: nativas e exóticas. Nova Odessa: Instituto Plantarum, $2^{\mathrm{a}}$. ed. 2008. 544 p.

MENDES, A. M. S.; FIGUEIREDO, A. F.; SILVA, J. F. Crescimento e maturação dos frutos e sementes de urucum. Revista Brasileira de Sementes, Londrina, v. 28, n. 1, p. 133 - 141, 2006.

MORAIS, O. M.; SÃO JOSÉ, A. R. Influência do teor de umidade das sementes de urucu (Bixa orellana L.) sobre o percentual de sementes duras. In: SÃO JOSÉ, A. R.; REBOUÇAS, T. N. H. A cultura do urucum no Brasil. Vitória da Conquista: Universidade Estadual do Sudeste da Bahia, 1990, p. 88-90.

PICOLOTTO, D. R. N.; THEODORO, J. V. C.; DIAS, A. R.; THEODORO, G. F.; ALVES, C. Z. Germinação de sementes de urucum em função de métodos de superação de dormência e temperaturas. Pesquisa Agropecuária Tropical, Goiânia, v. 43, n. 3, p. 232 - 238, 2013.

PIEREZAN, L.; SCALON, S. P. Q.; PEREIRA, Z. V. Emergência de plântulas e crescimento de mudas de jatobá com uso de bioestimulante e sombreamento. Cerne, Lavras, v. 18, n. 1, p. 127 - 133, 2012.

PRADO NETO, M.; DANTAS, A. C. V. L.; VIEIRA, E. L.; ALMEIDA, V. O. Germinação de sementes de jenipapeiro submetidas à pré-embebição em regulador e estimulante vegetal. Ciência e Agrotecnologia, Lavras, v. 31, n. 3, p. 693 - 698, 2007.

SANTOS, C. A. C.; PEIXOTO, C. P.; VIEIRA, E. L.; CARVALHO; E. V.; PEIXOTO, V. A. B. Stimulate ${ }^{\circledR}$ na germinação de sementes, emergência e vigor de plântulas de girassol. Bioscience Journal, Uberlândia, v. 29, n. 2, p. 605 - 616, 2013a.

SANTOS, C. A. C.; VIEIRA, E. L.; PEIXOTO, C. P.; LEDO, C. A. S. Germinação de sementes e vigor de plântulas de maracujazeiro amarelo submetidos à ação do ácido giberélico. Bioscience Journal, Uberlândia, v. 29, n. 2, p. $400-407,2013$ b. 
SANTOS, C. M. G.; VIEIRA, E. L. Efeito de bioestimulante na germinação de sementes, vigor de plântulas e crescimento inicial do algodoeiro. Magistra, Cruz das Almas, v. 17, n. 3, p. 124 - 130, 2005.

SCALON, S. P. Q.; LIMA, A. V.; SCALON FILHO, H.; VIEIRA, M. C. Germinação de sementes e crescimento inicial de mudas de Campomanesia adamantium Camb.: efeito da lavagem, temperatura e de bioestimulantes. Revista Brasileira de Sementes, Londrina, v. 31, n. 2, p. 96 - 103, 2009.

SCALON, S. P. Q.; MASETTO, T. E.; MATOS, D. S. C.; MOTTA, L. Condicionamento fisiológico e níveis de sombreamento em sementes de barbatimão (Stryphnodendron polyphyllum (Mart.) e S. adstringens (Mart.) Coville). Revista Árvore, Viçosa, v. 38, n. 1, p. 145 - 153, 2014.

STOLLER DO BRASIL. Stimulate ${ }^{\circledR}$ Mo em hortaliças. Cosmópolis: Stoller do Brasil-Divisão Arbore, 1998. (Informe Técnico)

TAIZ, L.; ZEIGER, E. Fisiologia Vegetal. Porto Alegre: Editora Artmed, 4ª ed. 2008. 820 p.

VIEIRA, E. L.; CASTRO, P. R. C. Ação de bioestimulante na germinação de sementes, vigor de plântulas, crescimento radicular e produtividade de soja. Revista Brasileira de Sementes, Londrina, v. 23, n. 2 , p. 169 $174,2001$. 
FLORESTA, Curitiba, PR, v. 48, n. 3, p 293-302, jul/set.2018

Neto, A.C.A. et.al. 